\title{
The Training Mode Reform of Physical Practical Talents Emphasizing on Innovation Ability
}

\author{
Shiming Hao, Liben Li, Xinzhong Li, Xiaoyang Gong \\ School of Physics and Engineering, Henan University of Science and Technology, Luoyang, China \\ Email:s_m hao@126.com
}

Received November $13^{\text {th }}$, 2013; revised December 13 $3^{\text {th }}, 2013$; accepted December $20^{\text {th }}, 2013$

\begin{abstract}
Copyright (c) 2014 Shiming Hao et al. This is an open access article distributed under the Creative Commons Attribution License, which permits unrestricted use, distribution, and reproduction in any medium, provided the original work is properly cited. In accordance of the Creative Commons Attribution License all Copyrights $\mathbb{C}$ 2014 are reserved for SCIRP and the owner of the intellectual property Shiming Hao et al. All Copyright @ 2014 are guarded by law and by SCIRP as a guardian.
\end{abstract}

\begin{abstract}
The quality education is to develop students' creative spirit and practical ability. Physics teaching can offer strict training for students in different scientific experiments, calculation and thinking; cultivate their ability in analyzing and solving problems and enhance their science quality and creative ability. This paper puts forward that the critical point of College Physics' reform in the applied-oriented college is to build up a practical system in physics' teaching. In order to meet the social needs, a new educational concept should be established, with scientific and reasonable teaching content as well as the advanced teaching methods. According to their teaching practice, the authors talk about some points on how to develop students' science quality and creative ability from the angle of upgrading teaching contents and reforming teaching way.
\end{abstract}

Keywords: Teaching Reform; Innovation Ability; Physics; Teaching Content; Engineering University

\section{Introduction}

In the reform process of education to promote quality education, highlighting the students' innovative ability, and actively exploring ways and means to train innovative and practical high-quality talents, are higher education theme of reform and development. In recent years, Chinese higher education has been considerably developing and enrollment continues to expand. There has also been the employment problem of college graduates. On the surface, this is mainly because the university-trained people are not well adapted to social changes to meet the social long-term needs, resulting in a relative surplus of talent and employment difficulties. But the deep reasons are mainly the poor cultural education, narrow professional education and strong common constraints (Pei, Cui, \& Sun, 2013). Deficiency of innovative consciousness and innovative ability is its main performance. The level of talent depends largely on the quality of its innovative consciousness and innovative ability, which is the bottleneck problem in the current higher education.

Physics is the foundation of today's high-tech innovation and development. It's also the backbone of a variety of technical disciplines. Cross professional expertise includes optics, engineering physics, semiconductors and materials expertise and so on. At present, China's demand for physical professional talent is still in short supply, but the surface is a student employment pressure. Society requires physics majors should have a solid theoretical foundation and application of physical experience, but the innovation ability in practice is the key to decide whether they can turn into personnel in many engineering and technical areas. Based on the big background of the demand for personnel training coupled with building an innovation-oriented country and international economic integration, it is important to speed up education reform and development, and put the important connotation of quality education into all levels of education process (Gess-Newsome, Southerland, Johnston, \& Woodbury, 2003).

In teaching practice, in accordance with this idea to set the curriculum, teaching and teaching content put opening innovative ideas throughout the physics undergraduate practice teaching (Henderson, \& Dancy, 2008). I hope this exploration can provide a reference for better training, bring up high level with innovative practical talents, build an innovation-oriented country, enhance independent innovation capability as well as provide the most important driving force for the sustainable development of high-tech industries.

\section{Analysis of Current Situation}

Physics majors students have solid basic knowledge, general theory, good at finding the problem, thinking, with a certain sense of innovation, but creative thinking, innovation and practical ability was poor, innovative personality has not yet formed. The formation of these abilities and qualities are needed step by step guide and training. Physics majors students generally have innovative motivation, creative desires, but the school can provide the environment for innovation is limited, the innovation and atmosphere is lack. The students' creative potential is difficult to play and innovation capability is difficult to obtain.

On the other hand, the students do not make good use of existing resources and conditions, not spontaneously create their own resources and conditions needed. In addition, the teaching 
mode, which is not conducive to the development of students' personality and talents; examination methods and examination content to guide students to dull reading; evaluation of students test scores be the main advantages and disadvantages of the curriculum, etc., have hindered the students' innovative consciousness and creative ability.

1) Narrow curriculum limiting students' creative ability. Since the physical professional courses generally are difficult, arduous, students only exercise in the narrow range of professional activities and ignore the study of humanities and social science knowledge and adjacent disciplines, thus limiting their horizons, affecting the innovation ability.

2) Experimental teaching model is obsolete and teaching effect is not ideal.

3) Research environment and atmosphere of research and innovation ability are lack.

4) Lack of effective internal and external practice ground. School laboratory experiments mainly complete the curriculumexperiment, open management model is not enough. Experimental practice ground has following features: little cost of hardware, lack of effective cycle mechanism.

5) The evaluation of students and teachers is not enough scientific evaluation mechanism. Currently evaluation criteria are academic students, and thus lead to a certain extent, onesided pursuit of student academic performance, neglect other capabilities, especially research innovation ability. For the evaluation of teaching behavior also look at the number of teachers to teach students the knowledge and the students to acquire knowledge of the situation, do not pay attention to teachers in the teaching process or pay attention to discovering whether good or ask a question, do not focus on evaluation of teachers to students' creative thinking ability.

\section{Specific Content of Reform}

1) Revising training program, optimizing the course structure and setting diversity training direction.

Ability to innovate comes from the basics of generosity and good quality, just mastering a single professional knowledge is difficult to achieve. Therefore, it is important to enhance students' connotation and denotation of professional basic education and construct a reasonable curriculum system. First, to optimize the course structure, according to the "fewer but better" principle set compulsory to ensure that students have a more solid foundation of knowledge. Increasing the proportion of elective courses, allowing students to choose elective courses interdisciplinary or interdisciplinary, impel students having a strong comprehensive interdisciplinary training. By means of hierarchical courses, elective courses as far as possible combination of the aptitude, interest and learning and improving their access to information, students have access to cutting-edge development of various disciplines to understand the trend of technological development and seize the future changes law.

2) Reform of classroom teaching and teaching forms, putting the cultivate of innovation ability into the classroom.

Classroom teaching is the basic component of teaching. students "innovative spirit and ability must also penetrate into the process of teaching subjects. To combine the students" cognitive levels and life experience, the creation of new teaching scenarios to stimulate students to actively explore desires. In teaching, creating a classroom atmosphere to encourage students' creativity, using various forms of classroom teaching, so that students consciously take the initiative to learn. Strengthen the mutual penetration and cross-disciplinary integration, broaden students' thinking space, is conducive to the improvement of the overall quality of students. By means of the integration of knowledge and high-tech frontier and increasing the amount of information the classroom to inspire students' innovative spirit (Driel, Beijaard, \& Verloop, 2001).

3) Implementation three-dimensional hierarchical teaching model of experimental class of to explore opening experimental teaching system.

Taking full advantage of equipment and faculty of Henan province physics experiment teaching demonstration center, we explore and improve the implementation of the open experimental teaching method and application in the classroom teaching, laboratory skills competition, innovative experiment design competition, photonics design competition, the experimental model competition, mathematical contest in modeling, and undergraduate graduation design (thesis). We reform laboratory management mechanism, and explore the opening laboratory management and institutions (Sun, 2006).

4) Reforming and improving students' scientific and technological innovation system, establishing internal innovation practice ground.

Implementation of student research training program to guide students to conduct research under the guidance of teacher training; teachers encourage students to participate in research projects, scientific research; hired well-known experts and scholars do academic reports for students, so that students understand the academic development of physics frontier; encourage students to declare student research training program, scientific and technological innovation projects, through scientific research to promote teaching to enhance students' scientific literacy and scientific spirit. In the creation of innovative laboratory, we actively introduce funding for students on campus to create innovative practice base.

5) The establishment and expansion of colleges, enterprises and training model, the establishment of campus practice ground, build a new model of personnel training.

Establishment and expansion of colleges, enterprises and training mode, and promote undergraduate education and social integration demand for talent to enhance students' employability, build a new model of personnel training. We establish joint training model with enterprises closely to physics, such as Luoyang CAMA control, the Four Seasons Muge Ltd et al, to improve the students' practical ability, training services for the regional economy practical talents.

6) Reforming and improving the evaluation system, establishing and improving the innovation incentives.

Education Management evaluation is a special implementation of control measures and is an important part of education management. Evaluation of the students not only to examine the comprehensiveness of the importance of knowledge, but also to focus on capacity (especially innovation ) of the test. We evaluate the learning effect through diversification of exam, exam time autonomy, or the use of non-exam evaluation study by writing special reports, writing academic papers, research projects and other forms of assessment in science.

While building on students' awareness of innovation, creativity, innovation positive incentive mechanism, namely giving positive incentives and rewards to the students having a variety of innovative behavior and outcomes. Evaluation of teaching behavior of teachers not only look at the number of teachers to 
impart knowledge to students and students to acquire knowledge of the situation, it also depends on its ability to focus on training students' creative thinking ability.

\section{Preliminary Results and Practical Effects}

1) Facilitating the formation of new physics professional training programs and personnel training mode conducive to students "innovative ability, creating a training system conducive to students" innovative ability. Combining students "Innovation Ability basis, presenting and establishing the physical training system and platform of professional students" innovative ability from both hardware and software.

2) Establishing and improving hierarchical opening experimental teaching system and new laboratory management operation mode. Building open experimental teaching management sites of physics experiment teaching demonstration center.

3) Establishing and perfecting physics student research training program system and the research project system. Undergraduate Research Training Program for credits and effort, funding and support teaching conditions, requirements for instructors, requirements for students, scheduling, project management and put forward clear and specific requirements, forming a perfect system.

4) Establishing joint training system of colleges and enterprises. the formation of the specific system for cultured form, implementation, and evaluation.

5) Setting game system of specification experimental skills contest, challenge cup, mathematical modeling contests, and creating a favorable environment for innovation and creative atmosphere.

Through a series of reforms, student increase interest in learning, improving positive initiative, and actively participating the lab work and the teacher's task; the proportion of students participate in business practices and improving working ability. Many students achieve frequently good results at the national, provincial competitions. High quality of the research reflecting project, was published at least 36 research papers. The results of the reform project teaching object directly benefit two professional Institute of Physics and Engineering (Materials Physics, Applied Physics) students of more than 300 people. More than 4000 engineering students obtain a benefit from opening experiments. Project results serve as a model of teaching and guiding role for other science and engineering majors, and expect to play the role of radiation and learn to the training of creative ability for similar colleges and universities of the province and the country's science and engineering students.

\section{Acknowledgements}

This work was supported by Henan provincial higher education teaching reform project of China (No. 2012SJGLX149).

\section{REFERENCES}

Driel Van, J. H., Beijaard, D., \& Verloop, N. (2001). Professional development and reform in science education: The role of teachers' practical knowledge. Journal of research in science teaching, 38, 137-158.

http://dx.doi.org/10.1002/1098-2736(200102)38:2<137::AID-TEA10 $01>3.0 . \mathrm{CO} ; 2-\mathrm{U}$

Gess-Newsome, J., Southerland, S. A., Johnston, A., \& Woodbury, S. (2003). Educational reform, personal practical theories, and dissatisfaction: The anatomy of change in college science teaching. American Educational Research Journal, 40, 731-767. http://dx.doi.org/10.3102/00028312040003731

Henderson, C., \& Dancy, M. H. (2008). Physics faculty and educational researchers: Divergent expectations as barriers to the diffusion of innovations. American Journal of Physics, 76, 79. http://dx.doi.org/10.1119/1.2800352

Pei, S. X., Cui, F. P., \& Sun, T. T. (2013). The unity of scientific literacy education and humanistic spirit education in higher education. Social Sciences \& Humanities, 1, 121-125.

Sun, W. B. (2006). Reform and practice of opening innovative experimental teaching. Research and Exploration in Laboratory, 2, 148151.

Zhang, X. J., \& Wang, S. P. (2005). Reforming experimental teaching all-roundly to cultivate students' innovative abilities [J]. Research and Exploration in Laboratory, 1, 4-6. http://en.cnki.com.cn/Article_en/CJFDTOTAL-SYSY200501002.ht m 